Journal Universitas Muhammadiyah Gresik Engineering, Social Science, and Health International Conference (UMGESHIC)

UMGCINMATIC : $1^{\text {st }}$ Rethinking Education during Covid-19 Era: Challange and Innovation

\title{
MARKETING STRATEGY ANALYSIS OF LEATHER CRAFT PRODUCTS IN UD. IRWAN JAYA IN THE TIME OF COVID-19 WITH SWOT METHODS and QSPM
}

\author{
Author \\ Rachmat Noviawan $^{1}$, Elly Ismiyah ${ }^{2}$, M. Zainuddin Fathoni ${ }^{3}$ \\ 1,2,3 Engineering Faculty, University of Muhammadiyah Gresik \\ rachmat1332@gmail.com ${ }^{1}$, ismi_elly@umg.ac.id ${ }^{2}$
}

\begin{abstract}
UD. Irwan Jaya is one of the SME leather craftsmen in Putat Village, Kebomas District, Gresik Regency and has been in this business for approximately 30 years. From this leather, the goods that the UKM can produce are wallets and bags. Based on the results of an interview with Mr. Irwan as the business owner, current sales conditions tend to decline in a few months in July 2020 - May 2021. This is influenced by the COVID-19 outbreak that has hit almost the entire world, affecting several industrial sectors including SMEs in the city of Gresik as well. experienced a decrease in the level of sales so that the profits that can be obtained are only around 7\% within 1 month (Narto \& Gatot, 2020). This condition requires the selection of a marketing strategy through the identification of the internal and external factors of SMEs. The selection of this strategy aims to improve and develop SMEs so that they can survive in uncertain conditions, so that in the preparation and formulation of the marketing strategy, a scientific approach will be used in the form of integration of the IFE-EFE Matrix SWOT method and QSPM (Quantitative Strategic Planning Matrix). SWOT analysis is based on logic that can maximize strengths and opportunities, but simultaneously minimize weaknesses and threats (Rangkuti, 2005). The next step is to determine strategic priorities from several alternatives resulting from the SWOT analysis using the QSPM method. From the results of the SWOT analysis, the company's position is in cell $\mathrm{V}$, namely the hold and mountain strategy and gets 8 strategies, then determines the prioritized strategy using QSPM. The prioritized strategy is the strategy of creating an online store as a technology in business
\end{abstract}

Keywords: Marketing, SWOT, QSPM 


\section{INTRODUCTION}

Business has been present since human existence on this earth and developed along with the times. Business has undergone many changes after the end of colonialism and imperialism (Sam'un \& Zaenal, 2015). Especially with the ongoing globalization, business is experiencing a very astonishing change. Starting from the people involved, the fields that can be used for business development, as well as business facilities and infrastructure. Business also has an important role both for society and the economy of a country. Small and Medium Enterprises (SMEs) cannot be denied being able to help in improving the Indonesian economy, therefore the empowerment and development of SMEs is very necessary.

UD. Irwan Jaya is one of the SME leather craftsmen in Putat Village, Kebomas District, Gresik Regency and has been in this business for approximately 30 years. In carrying out their business operations, these SMEs work on a design to order product that is made according to the design of the consumer and make to order products are made after receiving orders from consumers not in the amount per unit (wholesale). These SMEs also carry out business operations in the form of unit goods (retail). . From this leather, the goods that the UKM can produce are wallets and bags. The product is made from cowhide and synthetic leather which has excellent durability, the shape is more compact and minimalist, very suitable for use by modern men and women, besides that, the models of leather wallets and bags are also timeless and the products are sewn by experienced tailors in sewing products. leather special. UD. Irwan Jaya does marketing by distributing its products in Gresik and Pasuruan areas from the owner's business relations with prices for wallets ranging from Rp. 75,000 Rp. 150,000 and for bags ranging from Rp. 200,000 - Rp. 500,000 depending on the difficulty level of manufacture.

Based on the results of an interview with Mr. Irwan as the business owner, current sales conditions tend to decrease in a few months in July 2020 - May 2021. It can be seen in Figure 1 for sales data before the pandemic and the pandemic period. This is influenced by the COVID-19 outbreak that has hit almost the entire world, affecting several industrial sectors including SMEs in the city of Gresik which also experienced a decline in sales so that the profits that can be obtained are only around 7\% within 1 month (Narto \& Gatot, 2020). This condition requires the selection of a marketing strategy through the identification of the internal and external factors of SMEs. The selection of this strategy aims to improve and develop SMEs so that they can survive in uncertain conditions like today. 


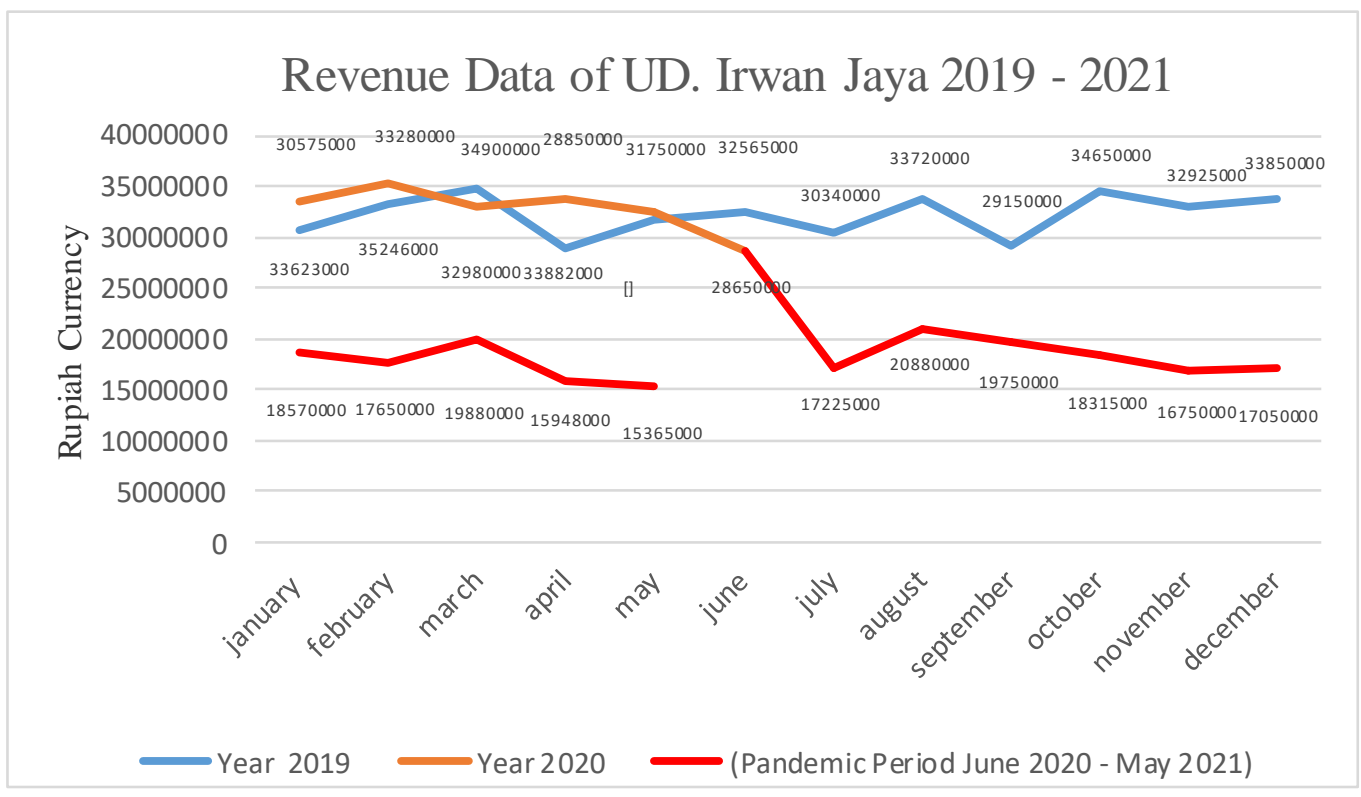

Figure 1. Revenue Data Graph of UD. Irwan Jaya periode

January 2019 - May 2021

From the graph, the company needs to implement the right marketing strategy so that the company can develop more, so that in the preparation and formulation of the marketing strategy, a scientific approach will be used in the form of integration of the IFE-EFE Matrix SWOT method and QSPM (Quantitative Strategic Planning Matrix). SWOT analysis identifies various factors systematically to formulate company strategy (Rangkuti, 2005). This analysis is based on logic that can maximize strengths and opportunities, but simultaneously minimize weaknesses and threats (Rangkuti, 2005). The next step is to determine strategic priorities from several alternatives resulting from the SWOT analysis, one method that can solve this problem is the QSPM (Quantitative Strategy Planning Matrix) method. QSPM is a tool to objectively evaluate alternative strategy options based on previously identified key internal and external success factors (Sugianto et al, 2017).

\section{METHODS}

The initial stage in the research methodology is conducting a preliminary study to obtain information related to the company. Here the researcher will identify the problems faced by the company and look for the causes of these problems. Data collection that will be needed for this research. Researchers collect data on the company's environmental analysis, namely:

a. Determination of respondents In this study, respondents were taken from the owners of UKM UD. Irwan Jaya, the head of operations, 1 person who has been a regular customer for the longest time and 2 employees who have worked for 5 years, and 1 person in the marketing department who has worked for 8 years, so a total of 5 respondents, this determination was 


\section{UMGCINMATIC : $1^{\text {st }}$ Rethinking Education during Covid-19 Era: Challange and Innovation}

Volume 1 No 2

based on people - people who know about UD. Irwan Jaya both in terms of process or product quality

b. Determination of internal and external factors

- Looking for the company's internal and external factors using literature from journals that are appropriate to UD's circumstances. Irwan Jaya and brainstorming with UD. Irwan Jaya

- Determination of internal and external factors using literature from journals that are in accordance with UD's circumstances. Irwan Jaya

c. Preparation and distribution of questionnaires to respondents Questionnaire preparation was carried out after the internal and external factors were determined. Questionnaires were distributed to respondents who had been determined, namely 5 people, out of 5 people were given several sheets of paper containing the weights and ratings of the company's internal and external factors which the respondents had to fill out properly and in accordance with the directions or instructions already on the questionnaire sheet. and mentoring the questionnaire so that if there are still those who don't understand, they can ask questions and give the right direction.

The data obtained will be used in data processing which includes the following activities:

1. Determination of the weight and rating of the IFE and EFE matrices by multiplying each weight and rating of the IFE and EFE matrix questionnaires that have been filled out by respondents

2. Determination of the IE matrix obtained from the combined results of the two IFE and EFE matriks matrices

3. Designing a SWOT matrix, making a matrix based on UD's internal and external factors. Irwan Jaya is needed for the formulation of alternative strategies.

4. Determination of alternative strategies is obtained from the combination of the SWOT matrix through brainstorming with UD. Irwan Jaya who will be a key factor and processed again in the QSPM method to get the best strategic priority

5. Determining the best marketing strategy priority with QSPM determining the best marketing strategy for the company to be used in marketing its products with the QSPM method by making a questionnaire that combines the results of the SWOT matrix and existing external internal factors with a value of 1-4 (not interesting - very interesting) to fill in the AS column and then multiplied by the weight to get the TAS then the highest TAS result becomes the strategy that can be proposed for UD. Irwan Jaya.

After processing the data, an analysis of the results of data processing is carried out, namely:

1. Analyze the company's internal and external factors in the form of strengths, weaknesses, threats and opportunities into the IFE-EFE matrix

2. Analyze the calculation of weights and ratings from the IFE-EFE . matrix

3. After analyzing the weight and rating calculations, we can determine alternative strategies from the SWOT matrix

4. From the results of the SWOT matrix analysis, alternative strategies will be weighted with QSPM to determine the best strategy priorities. 
The last stage is drawing conclusions from the results of the analysis and research conducted and constructive suggestions will be given.

\section{DISCUSSION}

The results of observations and interviews with owners, employees and consumers of UD. Irwan Jaya by using the SWOT method to determine alternative corporate strategies and followed by the QSPM method to determine the best strategic priorities for the company.

Table 5. IFE Matrix Result

\begin{tabular}{|c|c|c|c|}
\hline Internal Factors & Weight & Rating & $\begin{array}{c}\text { Weight X } \\
\text { Rating }\end{array}$ \\
\hline \multicolumn{4}{|l|}{ Strength : } \\
\hline Have very good product quality & 0,152 & 3,8 & 0,579 \\
\hline Design flexibility & 0,127 & 2,8 & 0,356 \\
\hline Collaboration with other companies & 0,118 & 3 & 0,335 \\
\hline Creative Potential & 0,110 & 2,8 & 0,308 \\
\hline $\begin{array}{l}\text { Good communication between business } \\
\text { owners and employees }\end{array}$ & 0,144 & 3,4 & 0,489 \\
\hline \multicolumn{4}{|l|}{ Weakness : } \\
\hline Limited designs available & 0,067 & 1,8 & 0,120 \\
\hline Less active using social media & 0,093 & 1,8 & 0,167 \\
\hline Limited delivery facilities & 0,084 & 1,8 & 0,151 \\
\hline Promotion is less intensive & 0,101 & 2,2 & 0,222 \\
\hline Total & 1,00 & & 2,747 \\
\hline
\end{tabular}

The results of the identification of the company's internal strategy factors in the form of strengths and weaknesses that are given weights and ratings get a score on the IFE matrix of 2,747. This figure shows that UD. Irwan Jaya is in an average position, which means that currently the company has average internal conditions or capabilities in utilizing strengths and overcoming existing business problems. IFE matrix shows that the main strength of UD. Irwan Jaya is a company that has 
excellent product quality with the highest score of 0.579 . With excellent product quality, it is expected to increase sales from UD. Irwan Jaya. Good communication between business owners and employees is UD's second strength. Irwan Jaya with a score of 0.489 while the third power is owned by UD. Irwan Jaya is design flexibility with a score of 0.356 . Then the other strength of UD. Irwan Jaya is a collaboration with other companies and the potential for creativity.

Table 6. EFE Matrix Result

\begin{tabular}{|l|c|c|c|}
\hline \multicolumn{1}{|c|}{ External Factors } & Weight & Rating & Weight X \\
Rating
\end{tabular}

The main opportunity for companies based on the EFE matrix is that the increase in online business provides opportunities for products to be widely marketed with a score of 0.405 . This external strategy factor becomes very important because it relates to the level of sales of UD products. Irwan Jaya. No competitors in the Gresik area are in second place with a score of 0.382, having customer connections is in third place with a score of 0.355 . Furthermore, it has an online store with a score of 0.335 and the last is high social media users with a score of 0.334 . 
The IE matrix is based on two key dimensions: the total IFE weighted score on the $\mathrm{x}$-axis and the total EFE weighted score on the y-axis. Here matrix IE UD. Irwan Jaya

TOTAL SKOR IFE

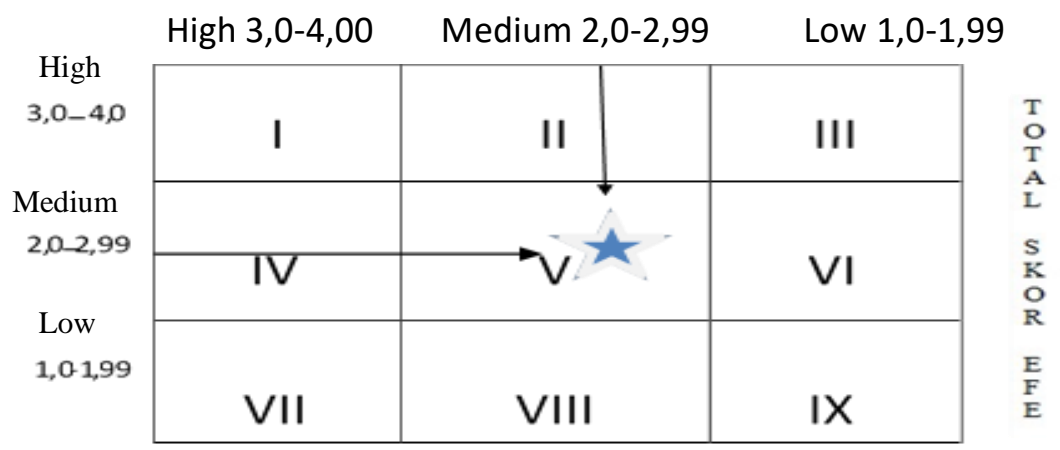

Figure 3 IE Matrix

Based on the IFE matrix which shows that the company is in the average position, which is indicated by a score of 2,747. While the EFE matrix produces a score of 2.581 which means the company has external factors also in the average position. If each of these values is placed in the I-E matrix, the company's current position is obtained, namely in cell V. In this cell the company is in an average internal condition and the response to external factors it faces is classified as moderate. The right strategy for a company in cell $\mathrm{V}$ is a hold and mountain strategy. Market penetration strategy and product development strategy are the two most used strategies for this cell.

After knowing the company's position and obtaining the core strategy based on strengths, weaknesses, opportunities, and threats, alternative strategies can be formulated. The formulation of this strategy is done by using the SWOT matrix. This matrix can clearly describe how the external opportunities and threats faced by the company can be adjusted to the strengths and weaknesses it has. This matrix can generate four cells of possible alternative strategies. The SWOT matrix provides various alternative strategies as is the case with the I-E matrix. The SWOT matrix formulates a strategy based on a combination of the IFE matrix and the EFE matrix. The results of the SWOT matrix can be seen in table 7 . 
Table 7. SWOT Matrix Result

\begin{tabular}{|c|c|c|}
\hline & $\begin{array}{l}\text { Strength } \\
\text { - Have excellent product quality } \\
\text { - Design flexibility } \\
\text { - Cooperation with other companies } \\
\text { - Creative potential } \\
\text { - Good communication between } \\
\text { business owners and employees }\end{array}$ & $\begin{array}{l}\text { Weakness } \\
\text { - Limited designs available } \\
\text { - Less active use of social media } \\
\text { - Limited delivery facilities } \\
\text { - Less intensive promotion }\end{array}$ \\
\hline $\begin{array}{l}\text { Opportunity } \\
\text { - Increasing online business } \\
\text { - High social media users } \\
\text { - Have customer connections } \\
\text { - There are no competitors in } \\
\text { the Gresik area } \\
\text { - Have an online shop }\end{array}$ & $\begin{array}{l}\text { SO Strategy } \\
\text { - Maintain product quality to maintain } \\
\text { connection and satisfaction to } \\
\text { consumers } \\
\text { - Creation of an online store as a } \\
\text { technology in online business }\end{array}$ & $\begin{array}{l}\text { WO Strategy } \\
\text { - Take advantage of the absence of } \\
\text { competitors to form branding with } \\
\text { product variants } \\
\text { - Increase promotion by using social } \\
\text { media }\end{array}$ \\
\hline $\begin{array}{l}\text { Threat } \\
\text { - Declining customer interest in } \\
\text { leather } \\
\text { - Raw material prices go up } \\
\text { - Utilization of technology is } \\
\text { still not maximized } \\
\text { - Delayed product distribution } \\
\text { due to PSBB } \\
\text { - Declining purchasing power } \\
\text { due to the pandemic }\end{array}$ & $\begin{array}{l}\text { ST Strategy } \\
\text { - Maintain good relationship and } \\
\text { communication with employees, } \\
\text { customers and raw material suppliers } \\
\text { - Designing new products and efficient } \\
\text { use of raw materials while } \\
\text { maintaining quality }\end{array}$ & $\begin{array}{l}\text { WT Strategy } \\
\text { - Innovate and develop in the } \\
\text { production and marketing } \\
\text { departments } \\
\text { - Create attractive promotional } \\
\text { strategies to attract a wider market } \\
\text { share }\end{array}$ \\
\hline
\end{tabular}


From the results of the SWOT matrix, four main strategies are obtained, namely SO strategy, WO strategy, ST strategy, and WT strategy which can be broken down into several strategies as follows:

1. SO Strategy

- Maintain product quality to maintain connection and satisfaction to consumers

- Creation of an online store as a technology in online business

2. WO Strategy

- Take advantage of the absence of competitors to form branding with product variants

- Increase promotion by using social media

3. ST Strategy

- Maintain good relationship and communication with employees, customers and raw material suppliers

- Designing new products and efficient use of raw materials while maintaining quality

4. WT Strategy

- Innovate and develop in the production and marketing departments

- Create attractive promotional strategies to attract a wider market share

This next step is the last step of the strategy formulation process. At this step, several alternative strategies are selected from the previous SWOT matrix. The analytical tool used at this stage is the Quantitative Strategic Planning Matrix (QSPM). The processing of the QSPM method is based on the results of the questionnaire that has been obtained in the previous step. After that, the next step is the AS value is multiplied by the weight value according to the IFE and EFE methods to produce the TAS value.

The results of the recapitulation of the as follows:

Table 8. Recapitulation of average TAS scores average value of TAS are

\begin{tabular}{|l|l|l|l|l|l|l|l|l|}
\hline Respondent & S 1 & S 2 & S 3 & S 4 & S 5 & S6 & S 7 & S 8 \\
\hline $\begin{array}{l}\text { Owner } \\
\text { UKM }\end{array}$ & 4,536 & 5,055 & 4,464 & 4,699 & 4,267 & 4,281 & 4,367 & 4,232 \\
\hline
\end{tabular}


UMGCINMATIC : $1^{\text {st }}$ Rethinking Education during Covid-19 Era: Challange and Innovation Volume 1 No 2

\begin{tabular}{|l|l|l|l|l|l|l|l|l|}
\hline $\begin{array}{l}\text { Mass } \\
\text { marketer the } \\
\text { longest } \\
\text { working }\end{array}$ & 4,702 & 5,088 & 4,687 & 4,692 & 4,220 & 4,389 & 4,539 & 4,279 \\
\hline $\begin{array}{l}\text { Regular } \\
\text { customer }\end{array}$ & 4,408 & 4,834 & 4,418 & 4,774 & 4,383 & 4.584 & 4,391 & 4,285 \\
\hline $\begin{array}{l}\text { Average } \\
\text { TAS }\end{array}$ & 4,548 & 4,992 & 4,523 & 4,721 & 4,290 & 4,418 & 4,432 & 4,265 \\
\hline
\end{tabular}

From the TAS results for each of the above strategies, UD's strategy can be prioritized. Irwan Jaya, namely the creation of an online store as a technology in business by registering UKM UD. Irwan Jaya in various e-commerce, created store profiles and store descriptions to make it easier for consumers who want to buy UD products. Irwan Jaya and attract a wider market share.

\section{CONCLUSION}

Based on the results and discussions that have been carried out, conclusions and suggestions can be drawn as follows:

Alternative strategies generated from the SWOT matrix can be formulated into several alternative strategies which are then carried out by QSPM analysis which produces the best strategic priorities to increase sales at UD. Irwan Jaya, namely the creation of an online store as a technology in business with an average TAS score of 4,992.

It is hoped that the company can try to implement the strategies that have been generated based on the SWOT analysis and QSPM analysis to increase sales during the pandemic

\section{REFERENCES}

Affandy, Mohammad Rizky. 2017. "Jurnal Matrik." Perencanaan Stategi Pemasaran Perhiasan Imitasi Dengan Metode Analisis SWOT dan AHP (Studi Kasus UD. AQILA) 18(1), 61-703

Adriani, Mega. 2020. Strategi Promosi Produk Kulit Untuk Meningkatkan Penjualan di Home Industri Kulit Chalsea Morris Kota Padang Panjang Menggunakan Analisis SWOT. Skripsi. Fakultas Ekonomi dan Bisnis Islam. Institut Agama Islam Negeri: Batusangkar

Ahmadi, Herman. 2013. Strategi Aliansi Dalam Menghadapi Globalisasi (Studi Pada Perusahaan Kerajinan Kulit di Kabupaten Magetan). Jurnal Widya Warta. 1, 165-178 Baroto, Teguh Dan Purbohadiningrat, Chandra. 2014. Analisis Strategi Pengembangan Bisnis Ppob Kipo Menggunakan Analisis Swot Dan Qspm. Jurnal Teknik Industri 15(1), 99- 
102. Universitas Muhammadiyah Malang.

David, Fred. 2009. Manajemen Strategi. Jakarta: Salemba Empat.

Kotler, Philip. 2008. Manajemen Pemasaran. PT. Gelora Aksara Pratama, Jakarta

Nur, A. T. (2013). Analisis SWOT Dalam Menentukan Strategi Pemasaran Sepeda Motor Pada PT. Samekarindo Indah. Samarinda. eJournal Administration Bisnis.

Qanita, Ariza. 2020. Analisis Strategi Dengan Metode Swot Dan Qspm (Quantitative Strategic Planning Matrix): Studi Kasus Pada D’gruz Caffe Di Kecamatan Bluto Sumenep. Jurnal Ilmiah Manajemen. 1(2), 11-24

Raharja, Sam'un Jaja. 2015. Filsafat Bisnis. Tangerang Selatan: Universitas Terbuka.

Rangkuti, Fredy. 2005. Analisis SWOT Teknik Membedah Kasus Bisnis. PT. Gramedia Pustaka Utama, Jakarta.

Sambas, Irma Khairani. 2017 Strategi Pengembangan Industri Kecil Menengah "Karya Mandiri” Kerajinan Dompet Kulit di Desa Maguwan Kecamatan Sambit Ponorogo. Jurnal Tata Kelola Seni. 3(1), 39-53

Setyorini. Hany, Mas'ud Efendy dan Imam Santoso. 2016. Analisis Strategi Pemasaran Menggunakan Matriks SWOT dan QSPM. Industria, 5(1), 46-53.

Satyarini, Ria dan Muliadi Palesangi. 2012. Analisis Peluang Dan Tantangan Pada Paguyuban Cahaya Terang Sebagai Ukm Pengrajin Kulit Di Sukaregang Garut. Bina Ekonomi Majalah Ilmiah Fakultas Ekonomi Unpar. 6(2), 28-42

Sugianto, Clara Amelinda dan Charly Hongdiyanto. 2017. "Perumusan Strategi Menggunakan Metode QSPM Pada Bisnis Sambal Noesantara." PERFORMA 2(1).

Tull. D S and L R Kahle. 1990. Marketing Management. Macmilan Publishing Company. New York..

Zulkarnaen, Halim Oky dan Sutopo. 2013. Analisis Strategi Pemasaran Pada Usaha Kecil Menengah (UKM) Makanan Ringan (Studi Penelitian UKM Snack Barokah di Solo). Dipenogoro Jurnal Of Management, 2(3), 1. 